\title{
KEANEKARAGAMAN PHYTOTHELMATA DI KAWASAN PEMUKIMAN DAN PERKEBUNAN DESA TAMAN SARI, GEDONG TATAAN, PESAWARAN
}

\section{DIVERSITY OF PHYTOTHELMATA AT RESIDENTIAL AND PLANTATION AREA IN TAMAN SARI VILLAGE, GEDONG TATAAN, PESAWARAN}

\author{
Welmi Nopia Ningsih ${ }^{1 *}$, Emantis Rosa ${ }^{1}$, Jani Master ${ }^{1}$ \\ 1Jurusan Biologi FMIPA Universitas Lampung \\ Jl. Prof. Dr. Sumantri Brojonegoro No.1 Bandar Lampung 35145 \\ *e-mail: nopia.welmi@yahoo.com
}

\begin{abstract}
ABSTRAK
Nyamuk merupakan vektor dari beberapa jenis penyakit yang merugikan manusia. Jumlah populasi nyamuk dapat dipengaruhi oleh tempat perindukan. Tempat perindukan nyamuk sangat beragam, salah satunya phytothelmata yang termasuk ke dalam tempat perindukan alami nyamuk. Phytothelmata merupakan tumbuhan penampung genangan air sehingga dapat digunakan sebagai tempat perindukan serangga termasuk nyamuk. Tujuan penelitian ini adalah mengetahui keanekaragaman phytothelmata di lokasi beberapa pemukinan dan perkebunan sekitar kawasan Desa Taman Sari, Gedong Tataan, Pesawaran yang dilaksanakan dari Januari-Maret 2016. Proses identifikasi nyamuk dilakukan di Laboratorium Botani, Jurusan Biologi, Fakultas Matematika dan IImu Pengetahuan Alam, Universitas Lampung. Analisis data menggunakan Indeks Keanekaragaman Shanon-Wiener dan Indeks Dominansi Simpons. Jenis phytothelmata yang ditemukan di area pemukiman sebanyak delapan jenis dan di perkebunan sebanyak tujuh jenis. Hasil penelitian menunjukkan keanekaragaman phytothelmata di area pemukiman dan perkebunan dalam kategori sedang $(1,835$ dan 1,613$)$ dan kategori rendah untuk indeks dominansi $(0,182$ dan 0,262).
\end{abstract}

Kata kunci: keanekaragaman, dominansi, phytothelmata, tempat perindukan

\begin{abstract}
Mosquitoes are vectors of several types of diseases that harm humans. Total population may be affected by the mosquito breeding places. Breeding places are very diverse, one of them is phytothelmata which included into natural breeding place. Phytothelmata are water container plant that can be used as breeding place of insects including mosquito. The purpose of this research were to know the diversity of phytothelmata at residental area in Taman Sari village, Gedong Tataan, Pesawaran on January-March 2016 in a few of residential and plantation area. Identification process were conducted in Botanical Laboratory, Biology Departement, Math and Science Faculty, Lampung University. Data were analyzed with Shanon-Wiener diversity index and Simpons domination index. Phytothelmata type found in residential areas as much as eight types and in plantations of seven types. The result showed that diversity of phytothelmata in residential and plantation area were at medium category $(1,835$ and 1,613$)$ and low for the category domination index $(0,182$ and 0,262$)$.
\end{abstract}

Keyword: diversity, dominantion, phytothelmata, breeding place

\section{PENDAHULUAN}

Phytothelmata merupakan salah satu tempat perindukan alami yang digunakan nyamuk untuk menyelesaikan siklus hidup (Rosa et al., 2012). Phytothelmata pada awalnya didefinisikan oleh Varga dalam
Kitching (2000) sebagai tumbuhan yang dapat dijadikan sebagai tempat penampungan air. Hal ini didasari hasil penemuan Varga yang melihat adanya jenis tumbuhan yang dapat menampung genangan air dan sebagai tempat 
berlangsungnya interaksi berbagai jenis flora dan fauna. Famili Culicidae merupakan salah satu famili yang banyak ditemukan mendiami sebagian besar phytothelmata.

Gedong Tataan merupakan salah satu daerah di provinsi Lampung dengan luas wilayah perkebunan $25,88 \%$ dan kawasan hutan negara $27,99 \%$ dari luas wilayah total kabupaten Pesawaran (Pesawarankab, 2013). Banyak dan luasnya area perkebunan diduga bahwa kawasan Gedong Tataan memiliki berbagai jenis phytothelmata yang dapat digunakan sebagai tempat perindukan nyamuk. Hal ini juga didukung oleh adanya kasus Demam Berdarah Denguedi Gedong Tataan yang cukup tinggi, demikian juga dengan penyakit lainnya yang ditularkan oleh nyamuk cenderung meningkat (Dinkesprov, 2012).Penelitian tentang phytothelmata juga sebelumnya telah dilakukan oleh Prasetyo (2015), dengan ditemukannya 17 jenis phytothelmata di kota Metro, provinsi Lampung yang berpotensi sebagai tempat perindukan alami nyamuk vektor demam berdarah. Untuk itu, penelitian ini dilakukan guna menemukan keberadaan tumbuhan yang termasuk kedalam golongan phytothelmata serta kaitannya sebagai tempat perindukan alami nyamuk.

\section{BAHAN DAN METODE}

Penentuan lokasi sampling dilakukan dengan menggunakan metode Purposive sampling di dua area pemukiman dan dua area perkebunan tiap dusun pada enam dusun yang ada di Desa Taman Sari, Gedong Tataan, Pesawaran. Pengambilan sampel dilakukan secara langsung di titik pengambilan sampel. Sampel phytothelmata yang ditemukan akan langsung diamati dan difoto lalu diidentifikasi. Bagi tanaman yang belum diketahui jenisnya akan diambil beberapa bagian tubuh tanaman dan kemudian akan diidentifikasi lebih lanjut di Laboratorium. Phytothelmata akan diidentifikasi menggunakan buku identifikasi Van Steenis (2006). Data yang didapatkan dianalisis menggunakan Indeks Keanekaragaman Shanon-Wiener (Michael, 1984) dengan rumus :

$$
\mathrm{H}^{\prime}=-\sum_{=1}^{s} \mathrm{Pi} \ln \mathrm{Pi},
$$

dimana $\mathrm{Pi}=\mathrm{ni} / \mathrm{N}$

Keterangan:

$\mathrm{H}^{\prime}$ : Indeks Shanon-Wiener

ni : Jumlah individu spesies ke-i

$\mathrm{N}$ : Jumlah total individu

Untuk mendapatkan nilai dominansi data juga akan dianalisis menggunakan Indeks Dominansi Simpsons (Odum, 1993) dengan rumus :

$$
\mathrm{Ds}=\sum(\mathrm{Pi})^{2},
$$

dimana $\mathrm{Pi}=\mathrm{ni} / \mathrm{N}$

Keterangan :

Ds : Indeks Simpson

ni : Jumlah individu spesies ke- i

$\mathrm{N}$ : Jumlah total individu 
HASIL DAN PEMBAHASAN

Pengamatan terhadap phytothelmata yang ditemukan di Desa Taman Sari, Kecamatan Gedong Tataan, Kabupaten
Pesawaran didapatkan hasil sebagai berikut :

Tabel 1. Komposisi jenis-jenis phytothelmata yang ditemukan di area pemukiman dan perkebunan

\begin{tabular}{|c|c|c|c|c|c|c|c|c|c|c|}
\hline \multirow[b]{2}{*}{ No } & \multicolumn{5}{|c|}{ Area pemukiman } & \multicolumn{5}{|c|}{ Area perkebunan } \\
\hline & Famili & Jenis & Tipe & $\Sigma$ & $\begin{array}{l}\text { Vol. } \\
\text { air }\end{array}$ & Famili & Jenis & Tipe & $\Sigma$ & $\begin{array}{c}\text { Vol. } \\
\text { air }\end{array}$ \\
\hline 1 & Araceae & $\begin{array}{l}\text { A. macrorhiza } \\
\text { C. esculenta }\end{array}$ & $\begin{array}{l}\mathrm{KD} \\
\mathrm{KD}\end{array}$ & $\begin{array}{l}1 \\
6\end{array}$ & $\begin{array}{l}28 \\
121\end{array}$ & Arecaceae & C. nucifera & $\begin{array}{l}\mathrm{KB} \\
\text { dan } \\
\mathrm{TG}\end{array}$ & 8 & 519,5 \\
\hline 2 & Bromeliaceae & G. sanguinea & $\mathrm{KD}$ & 4 & 460 & Bromeliaceae & A. comosus & $\mathrm{KD}$ & 2 & 22,8 \\
\hline 3 & Dracaenaceae & D. fragrans & $\mathrm{KD}$ & 6 & 180,35 & Dracaenaceae & D. fragrans & KD & 1 & 39 \\
\hline 4 & Malvaceae & T. cacao & $\mathrm{KB}$ & 1 & 126 & Malvaceae & T. cacao & $\begin{array}{l}\text { KB } \\
\text { dan } \\
\text { LP }\end{array}$ & 4 & 84,25 \\
\hline 5 & Musaceae & M paradisiaca & KD & 8 & 331,75 & Musaceae & M paradisiaca & KD & 10 & 305,5 \\
\hline 6 & Ruscaceae & $P$ angustifolia & KD & 3 & 105,75 & Pandanaceae & P. amaryllifolius & KD & 1 & 5,75 \\
\hline 7 & Sapindaceae & N. lappaceum & LP & 1 & 97 & Bambusaceae & Bambusa sp. & TB & 13 & 692,4 \\
\hline
\end{tabular}

Keterangan: $\mathrm{KD}$ = kelopak daun, $\mathrm{TG}$ = tanaman gugur, $\mathrm{KB}$ = kulit buah, TB =tunggul bambu, $\mathrm{LP}=$ lubang pohon, Vol. air = volume air $(\mathrm{ml})$, dan $\Sigma=$ jumlah individu

Pada Tabel 1, phytothelmata yang ditemukan di area pemukiman sebanyak tujuh famili dengan delapan jenis tumbuhan. Dari tujuh famili tumbuhan, yang paling banyak ditemukan jenisnya adalah famili Araceae dengan jenis tumbuhan Alocasia macrorhiza dan Colocasia esculenta sedangkan yang lainnya seperti famili Bromeliaceae dengan jenis Guzmania sanguinea, famili Dracaenaceae dengan jenis Dracaena fragrans, famili Malvaceae dengan jenis Theobrema cacao, famili Musaceae dengan jenis Musa paradisiaca, Ruscaceae denganjenis Pleomele angustifolia dan Sapindaceae dengan jenis Nephelium lappaceum hanya ditemukan satu jenis tiap familinya.
Musa paradisiaca merupakan jenis yang paling banyak ditemukan di lokasi penelitian yaitu sebanyak delapan individu sedangkan jenis yang paling sedikit adalahAlocasia macrorhiza yaitu sebanyak satu individu. Di area pemukiman, volume air paling banyak pada phytoythelmata yaitu jenis Guzmania sanguinea sebanyak $460 \mathrm{ml}$ dan yang paling sedikit pada Alocasia macrorhiza sebanyak $28 \mathrm{ml}$.

Jenis phytothelmata di area perkebunan sebanyak tujuh jenis yang terdiri dari tujuh famili tumbuhan yaitu, famili Arecaceaedengan jenisCocos nucifera, famili Bromeliaceaedengan jenisAnanas comosus, famili Dracaenaceaedengan jenisDracaena fragrans, famili Malvaceaedengan jenis Theobrema cacao, 
pada Alocasia macrorhiza sebanyak 28 ml. Hal ini dikarenakan Guzmania sanguinea memiliki morfologi tanaman dengan kelopak daun yang lebar dan lebih terbuka sehingga genangan air dapat tertampung secara maksimal sedangkan Alocasia macrorhiza memiliki ketiak daun yang cenderung menyempit sehingga genangan air menjadi terbatas.

Tumbuhan yang mewakili perkebunan hanya ditemukan satu jenis yang mewakili tiap familinya. Jenis yang paling banyak ditemukan di area perkebunan adalahBambusa sp. dan Musa paradisiaca. Hal tersebut karena wilayah Gedong Tataan merupakan daerah yang banyak digunakan sebagai area perkebunan terutama bagi komoditi kakao, pisang, kelapa, dan jagung (Febryano et al., 2009), sehingga jumlah tanaman seperti bambu dan pisang masih banyak ditemukan. Jenis yang sedikit ditemukan adalah Dracaena fragrans yang merupakan jenis tanaman hias dan Pandanus amaryllifolius yang merupakan jenis tanaman pangan yang banyak ditanam di area pekarangan rumah sehingga jarang ditemui pada area perkebunan.

Phytothelmata di area perkebunan yang paling banyak menampung genangan air yaitu, Bambusa sp. sebanyak 692,4 ml sedangkan paling sedikit pada Pandanus amaryllifolius sebanyak 5,75 ml. Bambusa sp. merupakan jenis phytothelmata yang tergolong tipe tunggul bambu yang memiliki bentuk silinder atau pipa sehingga jumlah air yang tertampung lebih banyak dibandingkan dengan Pandanus amaryllifolius yang merupakan tipe kelopak daun yang luas area genangannya lebih kecil. Bentuk pipa pada bambu juga diketahui memiliki suhu genangan air yang lebih dingin dibandingkan dengan tipe kelopak daun sehingga kadar penguapan air semakin berkurang (Rosa et al., 2016).

Penelitian Rosa et al. (2012), juga menyatakan bahwa pada phytothelmata tipe ketiak daun memiliki bentuk morfologi daun yang lebih terbuka sehingga terjadi adanya proses penguapan yang menyebabkan berkurangnya volume air yang tertampung.Semakin banyak volume air yang tertampung, maka akan semakin baik bagi tempat perindukan nyamuk.Kepadatan larva nyamuk paling dipengaruhi oleh volume air yang tertampung didalam phytothelmata selain oleh temperatur, $\mathrm{pH}$, dan kandungan kimia air (Rosa et al., 2016).

Keanekaragaman di area pemukiman dan perkebunan tergolong dalam tingkatan sedang dengan nilai indeks sebesar 1,835 dan 1,756. Dominansi phytothelmata di area pemukiman dan perkebunan tergolong dalam katergori rendah dengan nilai indeks 0,154 dan 0,213. 
Phytothelmata di area pemukiman lebih beranekaragam dibandingkan dengan area perkebunan karena jenis phytothelmata yang ada di area pemukiman lebih banyak dibandingkan area perkebunan. Hal tersebut dikarenakan jumlah jenis yang ditemukan akan berpengaruh terhadap nilai keanekaragaman. Menurut Kendeigh (1980), jika jumlah jenis yang ditemukan disuatu lokasi banyak maka indeks keanekaragaman akan tinggi. Area perkebunan memiliki jenis tanaman yang mendominansi dengan jumlah lebih banyak dibandingkan area pemukimansehingga nilai indeks dominansi di area perkebunan lebih tinggi.

\section{SIMPULAN}

Kesimpulan dari penelitian ini adalah jenis phytothelmata yang ditemukan di area pemukiman sebanyak delapan jenis dengan jenis yang paling banyak ditemukan adalah Musa paradisiaca. Jenis phytothelmata yang ditemukan di area perkebunan sebanyak tujuh jenis dengan jenis yang paling banyak ditemukan adalah Bambusa sp.. Indeks keanekaragaman total phytothelmata di area pemukiman sebesar 1,835 dan di area perkebunan sebesar 1,613 dan termasuk dalam keanekaragaman tingkat sedang. Dominansi total phytothelmata di area pemukiman sebesar 0,182 dan di area perkebunan sebesar 0,262 termasuk dalam dominansi rendah.

\section{DAFTAR PUSTAKA}

(Dinkesprov) Dinas Kesehatan Provinsi Lampung. 2012. Profil Dinas Kesehatan Provinsi Lampung Tahun 2012. [Internet]. Terdapat pada : Dinas kesehatan provinsi lampung. htm. Diakses pada :19 November 2015.

Febryano, I.G. Suharjito, D., Soedotomo, S. 2009. Pengambilan Keputusan Pemilihan Jenis Tanaman dan Pola Tanam di Lahan Hutan Negara dan Lahan Miliki : Studi Kasus di Desa Sungai Langka, Kecamatan Gedong Tataan, Kabupaten Pesawaran, Lampung. Forum Pasca Sarjana. 32(2) : 129-143.

Kendeigh, S.C. 1980. Ecology With Species Reference to Animal and Man.Prentice Hall of India. New Delhi.

Kitching, K. L. 2000. Food Webs and Container Habitats : The Natural History and Ecology of Phytothelmata. Cambridge University Press. New York.

Michael, P. 1984. Ecological Methods for Field and Laboratory Investigation. Tata McGraw-Hill Publishing Company Limited. New Delhi.

Odum, E. P. 1993. Dasar- Dasar Ekologi. Gajah Mada University Press.Yogyakarta.

(Pesawarankab). Kabupaten Pesawaran. 2013. Potensi Pertanian Kabupaten Pesawaran. [Internet].Terdapat pada : Pesawarankab.go.id. Diakses pada : 3 Januari 2016.

Prasetyo, A., Rosa, E., Yulianty. 2015. Keanekaragaman Phytothelmata Sebagai Tempat Perindukan Alami Nyamuk Demam Berdarah di Kota Metro Provinsi Lampung.Seminar Nasional Sains dan Teknologi. 578- 583. 
Rosa, E., Salmah, S., Dahelmi, Syamsuardi. 2012. Jenis dan Tipe Phytothelmata Sebagai Tempat Perindukan Alami Nyamuk di Beberapa Lokasi diSumatera Barat. Prosiding SNSMAIP. Sumatera Barat.

Rosa, E., Dahelmi, Salmah, S., Syamsuardi. 2016. Some Factor in Water Chemistery and Physics that Determines the Density of Diptera Larvae on Phytothelmata in Endemic Area's of Dengue Hemmoragic Fever. ARPN Journal of Agricultural and Biological Science. 11 (2).
Van Steenis, C.G. 2006. Flora. PT. Pradnya Paramita. Jakarta.

Varga, L. 1928. Ein Interessater Biotop der Bioconose von Wasserorganismen.Biologisches Zentralblatt. 41. 143-162.

Werdiningsih, H. $2007 . \quad$ Kajian Penggunaan Tanaman Sebagai Alternatif Pagar Rumah.Jurnal IImiah Perancangan Kota dan Pemukiman. 
Keanekaragaman Phytotelmata di Kawasan ... / 84 